\title{
Loss of methylation activates Xist in somatic but not in embryonic cells
}

\author{
Caroline Beard, En Li, ${ }^{1}$ and Rudolf Jaenisch ${ }^{2}$ \\ The Whitehead Institute for Biomedical Research and Department of Biology, Massachusetts Institute of Technology, \\ Cambridge, Massachusetts 02142 USA; ${ }^{1}$ Massachusetts General Hospital-East, Cardiovascular Research Center, \\ Charlestown, Massachusetts 02129 USA
}

\begin{abstract}
The mouse Xist gene, which is expressed only from the inactive $X$ chromosome, is thought to play a role in the initiation of $X$ inactivation. The $5^{\prime}$ end of this gene is fully methylated on the active $X$ chromosome and completely demethylated on the inactive $X$ chromosome, suggesting that DNA methylation may be involved in controlling allele-specific transcription of this gene. To directly investigate the importance of DNA methylation in the control of Xist expression, we have examined its methylation patterns and expression in ES cells and embryos that are deficient in DNA methyltransferase activity. We report here that demethylation of the Xist locus in male mutant embryos induces Xist expression, thus establishing a direct link between demethylation and expression of the Xist gene in the postgastrulation embryo. The transcriptional activity of Xist in undifferentiated ES cells, however, appears to be independent of its methylation status. These results suggest that methylation may only become essential for Xist repression after ES cells have differentiated or after the embryo has undergone gastrulation.
\end{abstract}

[Key Words: Xist gene; X chromosome inactivation; DNA methylation; transcriptional activity]

Received May 31, 1995; revised version accepted August 10, 1995.

Dosage compensation in mammals is accomplished by $\mathrm{X}$ chromosome inactivation, which ensures that an equal number of $\mathrm{X}$-linked genes is expressed in both sexes (Lyon 1961). In female embryos, $X$ inactivation first occurs in the extraembryonic lineages, where the paternal allele of the $\mathrm{X}$ chromosome is preferentially silenced (Takagi and Sasaki 1975; West et al. 1977; Monk and Harper 1979; Papaioannou et al. 1981; Harper et al. 1982). X inactivation is random in the epiblast, resulting in silencing of either the maternal or paternal X chromosome (Gardner and Lyon 1971; Takagi 1974; Rastan 1982). The process of inactivation begins at the $X$ inactivation center (Xic) (Russell 1963; Therman et al. 1974; Cattanach 1975; Mattei et al. 1981) which is required in cis, and spreads from the Xic to the adjacent chromosomal regions. The Xist gene, which maps to the Xic region in mouse and man, is thought to play a role in the initiation of $\mathrm{X}$ inactivation as it is expressed only from the inactive $\mathrm{X}$ chromosome and its expression precedes both imprinted and random $\mathrm{X}$ chromosome inactivation (Borsani et al. 1991; Brockdorff et al. 1991; Brown et al. 1991; Kay et al. 1993).

DNA methylation has long been proposed as a possible mechanism for controlling allele-specific transcription, as it is stable and heritable through many cell divisions, is known to affect gene expression, and is reversible through the germ line. Several groups have recently pre-

${ }^{2}$ Corresponding author. sented evidence linking DNA methylation and Xist expression. These investigators have shown that $\mathrm{CpG}$ sites at the $5^{\prime}$ end of the Xist gene become demethylated in the perinatal prospermatogonia and remain demethylated throughout preimplantation development (Norris et al. 1994; Ariel et al. 1995; Zuccotti and Monk 1995). These results are consistent with the hypothesis that male gamete-specific hypomethylation is important for the imprinting of the paternal X chromosome in the extraembryonic ectoderm and trophectoderm, which only express the paternal Xist allele, whereas the silent maternal allele is methylated (Norris et al. 1994; Ariel et al. 1995; Zuccotti and Monk 1995). Later in development, when the imprint is erased and $\mathrm{X}$ inactivation becomes random, the repressed Xist gene on the active $\mathrm{X}$ chromosome is fully methylated, whereas the expressed gene on the inactive X chromosome is hypomethylated (Norris et al. 1994). A strong correlation between methylation and $X i s t$ expression is further supported by the observation that in male embryonic stem (ES) cells, which contain only one X chromosome, the silent Xist gene is methylated (Norris et al. 1994). Undifferentiated female ES cells, which contain two active $\mathrm{X}$ chromosomes, do not express Xist. Upon differentiation, however, one Xist allele becomes activated and hypomethylated concomitant with random $\mathrm{X}$ inactivation.

The importance of DNA methylation in controlling the differential expression of paternal and maternal alleles of imprinted genes has been demonstrated in our laboratory using embryos that have two different muta- 
tions in the DNA methyltransferase gene (Dnmt) ( $\mathrm{Li}$ et al. 1992, 1993). One of these mutations, the Dnmt ${ }^{\mathrm{N}}$ allele, results in a partial loss of function (Li et al. 1992). Embryos homozygous for this mutation die at embryonic day 11 (E11) and their DNA, although substantially demethylated, still retains $30 \%$ of the wild-type level of 5-methylcytosine ( $\mathrm{Li}$ et al. 1992). A second, more severe mutation, the Dnmt ${ }^{\mathrm{S}}$ allele, is possibly a null mutation. Embryos homozygous for this mutation die at the 5-10 somite stage and their DNA is more demethylated than that of the Dnmt ${ }^{\mathrm{N}}$ homozygous embryos (Li et al. 1993, and in prep.). We have shown that monoallelic expression of three imprinted genes, H19, Igf2, and Igf2r, is altered in these mutant embryos (Li et al. 1993). Moreover, the extent of DNA hypomethylation, which differs in the two Dnmt mutants, dictates the severity of imprinted gene deregulation. In particular, we observed that expression of the $\mathrm{H} 19$ and Igf2 genes was altered in the weaker Dnmt ${ }^{\mathrm{N}}$ homozygous embryos, whereas $I g f 2 r$ gene expression was affected only in the more severe $\mathrm{Dnmt}^{\mathrm{N}} / \mathrm{Dnmt}^{\mathrm{s}}$ compound heterozygous or Dnmt ${ }^{\mathrm{s}}$ homozygous embryos. Furthermore, the CpG island, which is methylated on the expressed maternal allele of the Igf2r gene, was completely demethylated only in the latter mutant embryos. We were thus able to establish a causal link between DNA methylation and gene activity and we showed that methylation of the Igf2r gene was preferentially maintained under conditions of limiting maintenance methyltransferase.

In this report we have used both $\mathrm{Dnmt}^{\mathrm{N}}$ and Dnmt ${ }^{\mathrm{S}}$ homozygous ES cells and embryos to study the effects of demethylation on Xist expression. We show that demethylation of the Xist locus in male mutant embryos and differentiated male mutant ES cells induces Xist expression, thus demonstrating the importance of DNA methylation for maintaining the repression of this gene.

\section{Results}

Expression of Xist in male embryos deficient in DNA methyltransferase

To determine whether methylation is required for the repression of Xist transcription on the active $\mathrm{X}$ chromosome, Xist expression was examined in embryos deficient for DNA methyltransferase. RNA was isolated from E10.5 embryos homozygous for the Dnmt ${ }^{\mathrm{N}}$ mutation and analyzed for Xist expression by reverse transcriptase polymerase chain reaction (RT-PCR) using primers that are specific for mature spliced Xist RNA (Kay et al. 1993). Figure 1A demonstrates that as expected, Xist RNA was expressed in female wild-type and $\mathrm{Dnmt}^{\mathrm{N}}$ homozygous embryos (lanes 3,10 ). No Xist transcripts were seen in RNA isolated from wild-type or mutant male embryos (lanes $2,4,8,9,11$ ), suggesting that the level of overall hypomethylation achieved in $D n m t^{\mathrm{N}}$ mutant embryos did not alter the expected expression pattern.

To address whether a further reduction in the overall level of DNA methylation, which is seen in embryos carrying the more severe $\mathrm{Dnmt}^{\mathrm{s}}$ allele mutation, would result in Xist expression in mutant male embryos, we isolated RNA from E9.5 embryos that were either compound heterozygous Dnmt ${ }^{\mathrm{N}} / \mathrm{Dnmt}^{\mathrm{s}}$ or Dnmt ${ }^{\mathrm{s}}$ homozygous mutants. RT-PCR analysis showed very low levels of Xist expression in two of six of the Dnmt ${ }^{\mathrm{N}} / \mathrm{Dnmt}^{\mathrm{S}}$ male embryos analyzed (see Table 1 and Fig. 1A, lanes $1,6,7$; three mutant embryos shown), whereas five of five independently tested $\mathrm{Dnmt}^{\mathrm{S}}$ homozygous male embryos showed significant Xist expression (Fig. 1B; three mutant embryos shown).

It appeared that in $\mathrm{Dnmt}^{\mathrm{s}}$ homozygous embryos the Xist gene was expressed. Alternatively, the Xist transcription detected by RT-PCR may have been attributable to maternal contamination of the embryo samples. To determine whether the Xist expression seen in the $\mathrm{Dnmt}^{\mathrm{S}}$ homozygous male embryos was attributable to maternal contamination, cDNA synthesized from the embryonic RNA was also PCR amplified using primers that span the SalI site of the Dnmt gene. A 128-bp product, representative of the wild-type gene, was seen in the RNA samples of heterozygous and wild-type embryos but not in the Dnmts mutant embryos (Fig. 1C), indicating that the mutant embryo RNA was not contaminated with maternal tissue. The 600 -bp product that was amplified in the mutant embryo RNA samples (Fig. 1C) was cloned and sequenced and found to be attributable to amplification of an unrelated RNA. Because the development of the Dnmt ${ }^{\$}$ mutant embryos is delayed by 1 day when compared to normal littermates $(\mathrm{Li}$ et al. 1993), RNA from E8.5 wild-type male embryos was also analyzed by RT-PCR. No Xist expression was detected (data not shown). Finally, because the primers specific for Xist RNA span the HindIII restriction enzyme site, digestion of the RT-PCR products with this enzyme allowed us to confirm that the 578-bp product was attributable to the amplification of Xist sequences (data not shown). The results summarized in Table 1 indicate that the Xist gene was fully repressed in the Dnmt ${ }^{\mathrm{N}}$ homozygous embryos and activated in only some of the Dnmt ${ }^{\mathrm{N}}$ / $\mathrm{Dnmt}^{\mathrm{S}}$ embryos. Reproducible activation of the Xist gene was seen in all embryos homozygous for the more severe $\mathrm{Dnmt}^{\mathrm{s}}$ allele.

\section{Demethylation of the Xist gene correlates with Xist expression}

It has been proposed that methylation at the $5^{\prime}$ end of the Xist gene is associated with repression of this gene on the active $\mathrm{X}$ chromosome. To assess whether Xist expression correlated with Xist gene methylation, DNA from the various Dnmt mutant embryos or yolk sacs was digested with $E c o \mathrm{RV}$ and a methylation-sensitive restriction enzyme, HhaI, and analyzed by Southern blot using a $1.5-\mathrm{kb}$ probe that hybridizes to the $5^{\prime}$ end of the Xist gene (Fig. 2A). Figure 2B shows that low molecular mass bands $(0.8$ and $0.2 \mathrm{~kb})$ seen in both wild-type and mutant female yolk sacs were not detectable in DNA from $\mathrm{Dnmt}^{\mathrm{N}}$ homozygous male yolk sacs (similar results were 
A

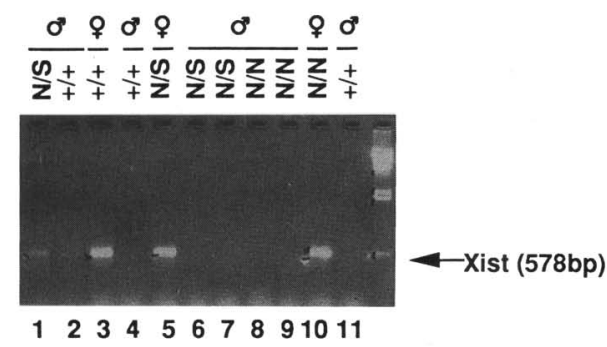

B

C
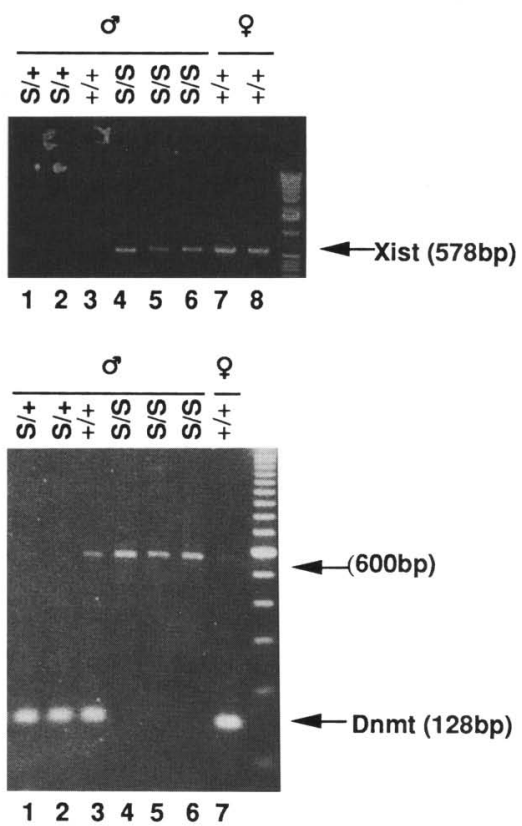

Figure 1. RT-PCR analysis of Xist expression in Dnmt mutant embryos. $(A, B)$ Total cellular RNA was prepared from individual E10.5 (Dnmt $\left.{ }^{\mathrm{N}} / \mathrm{Dnmt}^{\mathrm{N}}\right)$ or E9.5 $\left(\mathrm{Dnmt}^{\mathrm{N}} / \mathrm{Dnmt}^{\mathrm{S}}\right)$ and (Dnmt ${ }^{\mathrm{s}} / \mathrm{Dnmt}^{\mathrm{S}}$ ) embryos. RNA (2 $\left.\mu \mathrm{g}\right)$ was reverse transcribed using random hexamers. Half of the first strand product was subjected to 30 cycles of PCR amplification using cDNA primers specific for Xist transcription $(A, B)$ or wild-type Dnmt transcription $(C)$. Samples were then subjected to electrophoresis in a $2 \%$ agarose gel containing ethidium bromide. Molecular weight size markers $\lambda$ DNA-HindIII fragments $(A$, lane 12) and the BRL 1-kb DNA ladder $(B$, lane 9; $C$, lane 8$)$ are shown. The gel was photographed under UV illumination.

obtained using DNA isolated from embryos). These lower molecular mass fragments are attributable to demethylation of the expressed Xist allele on the inactive $\mathrm{X}$ chromosome (Norris et al. 1994). The fragment migrating at $\sim 3.3 \mathrm{~kb}$, which is diagnostic of complete methylation at all HhaI sites except $H$ haI $(1)$ or $H$ hal(2), is seen also in wild-type or heterozygous male embryos (Fig. 2D, lanes 3,41 . To assess the overall methylation level of mutant and wild-type embryos, the blot was stripped and probed with a Moloney murine leukemia virus (MoMuLV) cDNA. This probe allows detection of multiple endogenous retroviruses that are known to be highly methylated (Stuhlmann et al. 1981; Jahner et al. 1982) and, therefore, serves as an indicator of global genomic methylation levels. In contrast to the results ob- tained with the Xist probe, the MoMuLV probe revealed substantial hypomethylation of the genomic DNA in the Dnmt $^{\mathrm{N}}$ homozygous embryos (Fig. 2C, cf. lane 2 and lanes $1,3-5)$.

Southern blot analysis of DNA from Dnmt ${ }^{\mathrm{N}} / \mathrm{Dnmt}^{\mathrm{S}}$ compound heterozygous male embryos showed partial demethylation of the 5 ' region of the Xist gene in mutant embryos (Fig. 2D, lanes 1,2). Clearly, substantial levels of methylation were maintained as revealed by the presence of the $4.5-\mathrm{kb}$ full-length band that is generated only when all Hhal sites are methylated on the same allele. The prominent band at $3.3 \mathrm{~kb}$ and several bands migrating around $2.5 \mathrm{~kb}$ were attributable to partial demethylation of some $H$ haI sites within the EcoRV fragment. The methylation pattern of the $H 19$ gene was also analyzed in these mutant embryos to confirm that there was significant demethylation at another independent locus in the genome. Figure $2 \mathrm{E}$ shows that the differentially methylated region of the $H 19$ gene (Bartolomei et al. 1993; Brandeis et al. 1993; Ferguson et al. 1993) was completely demethylated in the $\mathrm{Dnmt}^{\mathrm{N}} / \mathrm{Dnmt}^{\mathrm{S}}$ mutant embryos.

Finally, when DNAs from male and female Dnmt ${ }^{\mathrm{s}}$ homozygous embryos were analyzed by Southern blot, we observed complete demethylation of HhaI sites as demonstrated by the presence of a prominent band at $0.8 \mathrm{~kb}$, which is diagnostic of demethylation of the Xist gene on the inactive $X$ chromosome (Fig. 2F, lanes 4-8). These results indicate that the Xist gene is more resistant to demethylation than either the $H 19$ gene or bulk genomic DNA under conditions of limiting levels of methyltransferase as achieved in the Dnmt mutant embryos. Furthermore, our results show a direct correlation between demethylation and expression of the Xist gene, suggesting that methylation of the $5^{\prime}$ end of the gene is involved in the control of Xist transcription.

\section{Expression of Xist is increased in male ES cell lines deficient in the DNA methyltransferase gene}

ES cells homozygous for the Dnmt ${ }^{\mathrm{N}}$ or Dnmt ${ }^{\mathrm{S}}$ mutations proliferate normally and are morphologically indistinguishable from wild-type cells (Li et al. 1992, 1993; H. Lei, P.S. Oh, R. Jütterman, R. Jaenisch, K. Goss, and E. Li,

Table 1. Summary of Xist expression in Dnmt mutant male embryos

\begin{tabular}{lccr}
\hline \multirow{2}{*}{$\begin{array}{l}\text { Dnmt } \\
\text { genotype }\end{array}$} & \multicolumn{2}{c}{$\begin{array}{c}\text { Xist expression } \\
\text { (no. of embryos) }\end{array}$} \\
\cline { 2 - 4 } & ++ & + & - \\
\hline wt & 0 & 0 & 10 \\
N/N & 0 & 0 & 5 \\
N/S & 0 & 2 & 4 \\
S/S & 5 & 0 & 0
\end{tabular}

The data in this table were derived from individual male embryos. RT-PCR analysis was as described in Fig. 1.1+1 A low, but detectable level of Xist expression. 


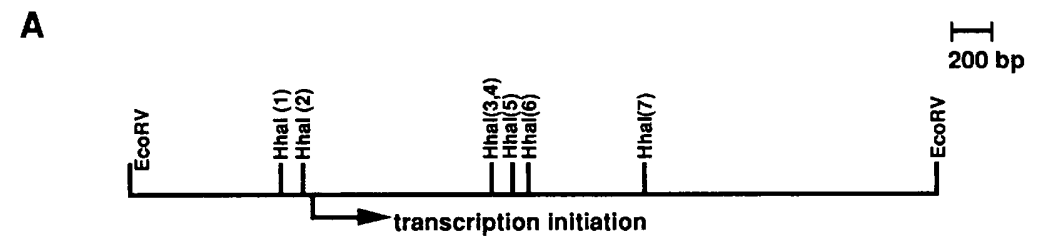

Figure 2. The relative resistance of Xist to demethylation in Dnmt mutant embryos correlates with expression of the gene. $(A)$ Schematic representation of the $5^{\prime}$ end of the Xist gene showing the positions of the methylation-sensitive restriction enzyme, $H h a \mathrm{I}$, and the probe used in this analysis. $(B, C)$ Southern blot analysis of the Dnmt ${ }^{\mathrm{N}}$ homozygous embryos (N/N). Approximately $5 \mu \mathrm{g}$ of genomic DNA isolated from individual E10.75 yolk sacs was digested with EcoRV and HhaI. The filter was hybridized with the $5^{\prime} X i s t$ cDNA probe $(B)$, stripped, and then rehybridized with the MoMuLV probe $(C) .(D, E)$ Southern blot analysis of the $\mathrm{Dnmt}^{\mathrm{N}} / \mathrm{Dnmt}^{\mathrm{S}}$ embryos (N/S). In each lane $\sim 2 \mu \mathrm{g}$ of genomic DNA from individual E9.5 yolk sacs was digested with EcoRV and HhaI and probed with the $5^{\prime}$ Xist probe $(D)$ or digested with Sacl and $H p a I I$ and probed with the $H 19$ probe $(E) .(F)$ Southern blot analysis of Dnmt ${ }^{\mathrm{S}}$ homozygous embryos (S/S). Approximately $2 \mu \mathrm{g}$ of genomic DNA from individual E9.5 embryos plus yolk sac were digested with EcoRV and HhaI and hybridized with the 5' $X i s t$ probe. Molecular mass (in kilobases) is marked at left.

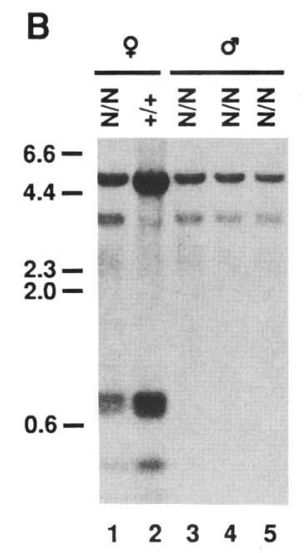

5. XIst cDNA probe

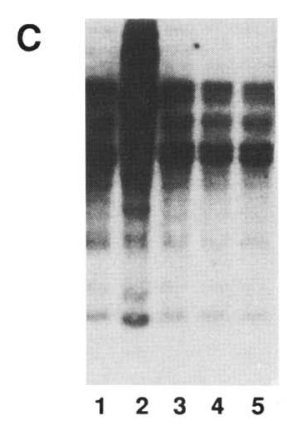

D

E

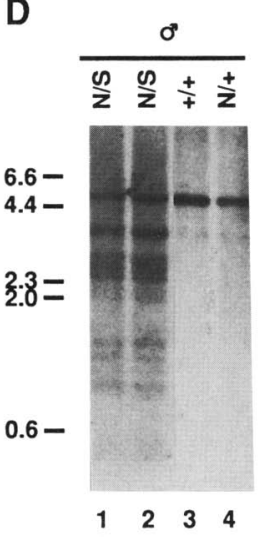

$\mathbf{F}$
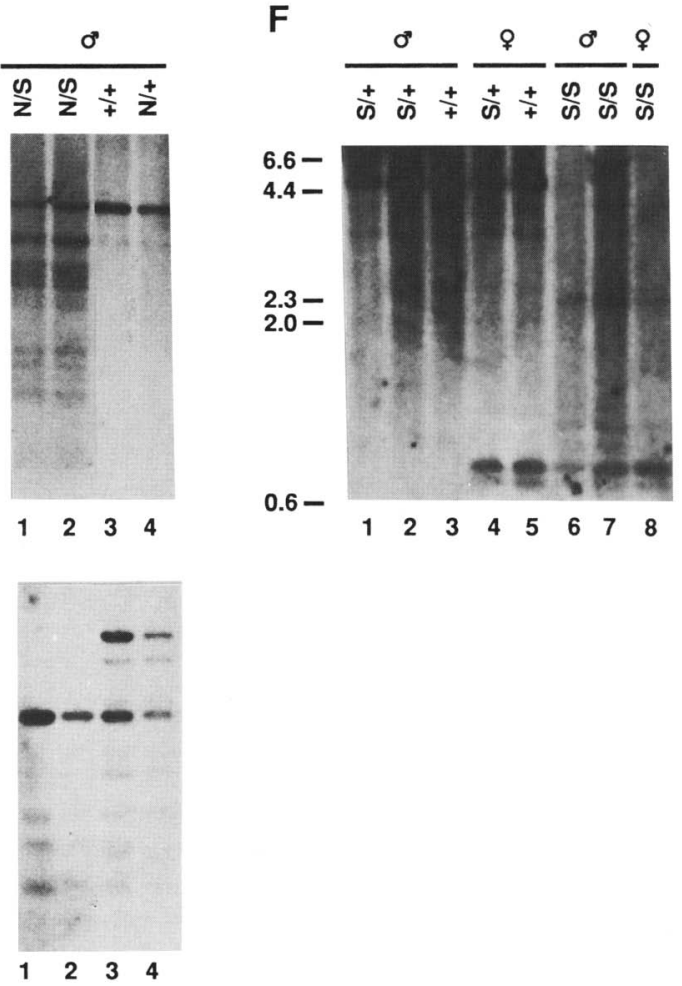

in prep.). These cell lines can be induced to differentiate and form embryoid bodies in vitro, although the Dnmt ${ }^{\mathrm{s}}$ mutant ES cells do not differentiate or proliferate to the same extent as the wild-type ES cells. We wished to determine whether Xist expression and methylation of the $X$ ist gene in mutant male ES cells would mimic what was seen in vivo in the homozygous male embryos. This was important because the paucity of material available from E8.5 or E9.5 embryos hampers the study of methylation and $\mathrm{X}$ inactivation in vivo.

Male ES cells, which contain a single $\mathrm{X}$ chromosome, do not express Xist in the undifferentiated state or after differentiation (Kay et al. 1993). We first analyzed Xist expression in undifferentiated wild-type and mutant male ES cells using RT-PCR. To exclude the possibility of Xist expression from embryonic fibroblast (EF) feeder cell contamination, ES cells were seeded on male EF cells that do not express the Xist gene. We were surprised to see a low but detectable level of Xist expression even in wild-type male ES cells (Fig. 3A, lane 1,4) which did not, however, appear to appreciably increase when the cells were induced to differentiate. Undifferentiated $\mathrm{Dnmt}^{\mathrm{N}}$ and $\mathrm{Dnmt} \mathrm{t}^{\mathrm{S}}$ mutant ES cells and an early passage wild-type female cell line V44 also showed a low level of Xist expression, which, in contrast to the wild-type male ES cells, increased substantially upon differentiation. RT-PCR analysis of the ES cells using primers specific for FGF-5, which is an early marker of differentiation (Hebert et al. 1991; Conover et al. 1993), showed a low level of expression in the undifferentiated ES cells (Fig. $3 \mathrm{~B})$, suggesting that the expression of Xist seen in the undifferentiated cultures might be attributable to cells that had differentiated or were poised to differentiate.

RNase protection analysis was used to quantitatively measure Xist expression to evaluate the degree of activation of this gene upon differentiation of the ES cells. Figure 4 shows that, as expected, high levels of Xist specific transcripts were seen in RNA from female but not male adult spleen (lanes 7,8). Although no Xist-specific RNA was detected in any of the undifferentiated ES cells, differentiation for 15 days induced a low level of Xist- specific RNA transcription in the Dnmt ${ }^{\mathrm{N}}$ mutant 
A

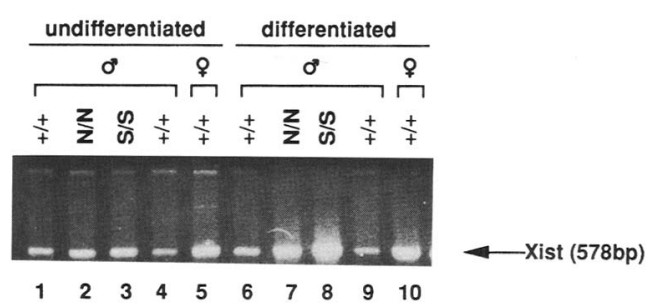

B

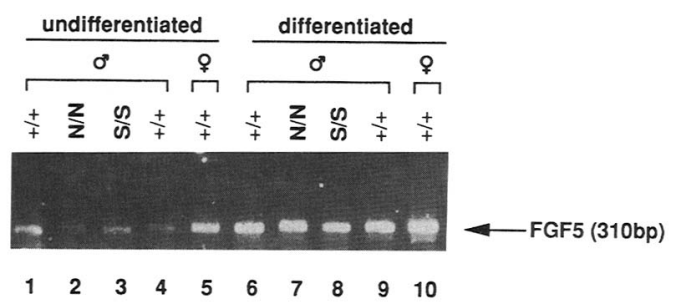

Figure 3. RT-PCR analysis of Xist expression in undifferentiated and differentiated Dnmt mutant ES cells. (A) Ethidium bromide-stained gel showing Xist expression in ES cells, undifferentiated and differentiated for 15 days. The higher molecular weight product, which is visible in lanes $1-5$ and 9, is attributable to amplification of contaminating DNA in these RNA samples. The wild-type male cell line in lanes 1 and 6 is $I 1$ and in lanes 4 and 9 is V18. V44 is the female cell line shown in lanes 5 and $10 .(B)$ Ethidium bromide-stained agarose gel showing FGF-5 expression in ES cells, undifferentiated and 3 days following differentiation as embryoid bodies.

ES cells and a significantly greater level of Xist RNA in the Dnmt ${ }^{\mathrm{s}}$ mutant ES cells. The level of expression of Xist in the Dnmt ${ }^{\mathrm{s}}$ mutant ES cells was comparable to that seen in RNA isolated from the spleen of an adult female. No Xist-specific RNA was detected in the differentiated male wild-type ES cells.

The results presented in Figures $3 \mathrm{~A}$ and 4 indicate that although the Xist gene is expressed at very low levels detectable only by RT-PCR in undifferentiated wildtype and mutant male ES cells, it is activated efficiently only in Dnmt mutant and wild-type female ES cells upon induction of differentiation.

\section{Methylation of the Xist gene in differentiated ES cells correlates with Xist expression}

To determine whether Xist expression correlated with demethylation of the Xist gene as was seen in vivo in the Dnmt mutant embryos, DNA from male Dnmt-deficient ES cells was analyzed as described in Figure 2. We were surprised to see that the Xist gene was partially demethylated in two different undifferentiated wild-type male cell lines, which did not show any Xist expression as measured by RNase protection. However, the level of methylation increased as differentiation proceeded (Fig. $5 \mathrm{~A}$, cf. lane 1 and 13 with lanes 4 and 16, respectively). Whereas the level of methylation in undifferentiated $\mathrm{Dnmt}^{\mathrm{N}}$ mutant ES cells was substantially less than in the wild-type cells, it also increased upon the induction of differentiation (Fig. 5A, lanes 5-8). DNA hypomethylation was, as expected, most pronounced in $\mathrm{Dnmt}^{\mathrm{s}} \mathrm{mu}$ tant ES cells; however, following differentiation an increase in methylation levels was less obvious (lanes 9-12) than in wild-type and Dmnt ${ }^{\mathrm{N}}$ mutant ES cells.

To investigate whether overall genomic methylation levels increased upon differentiation of wild-type and mutant ES cells, we digested samples of genomic DNA with HpaII and hybridized Southern blots with the MoMuLV probe and two repetitive probes, pMR134 and pMR150. pMR134 detects $\mathrm{Ll}$ sequences that are interspersed throughout the mouse genome with 30,000 copies of a 5- to 7-kb element (Voliva et al. 1983; Chapman et al. 1984), and pMR150 detects minor satellite sequences that are centromeric, tandemly repetitive elements of 120 bp with 50,000 copies per genome (Chapman et al. 1984). Both of these repetitive elements are highly methylated in adult somatic tissue (Chapman et al. 1984). When the Southern blot was hybridized with the MoMuLV probe or either of the two repetitive probes, we did not observe any significant increase in overall genomic DNA methylation levels upon differentiation of wild-type or mutant cells (Fig. 5B-D). Overall genomic DNA methylation levels in wild-type and Dnmt $^{N}$ homozygous ES cells as measured using the MoMuLV probe actually decreased after 15 days of differentiation (data not shown). We also noted that overall genomic DNA in undifferentiated wild-type ES cells was highly methylated in contrast to the $5^{\prime}$ end of the Xist

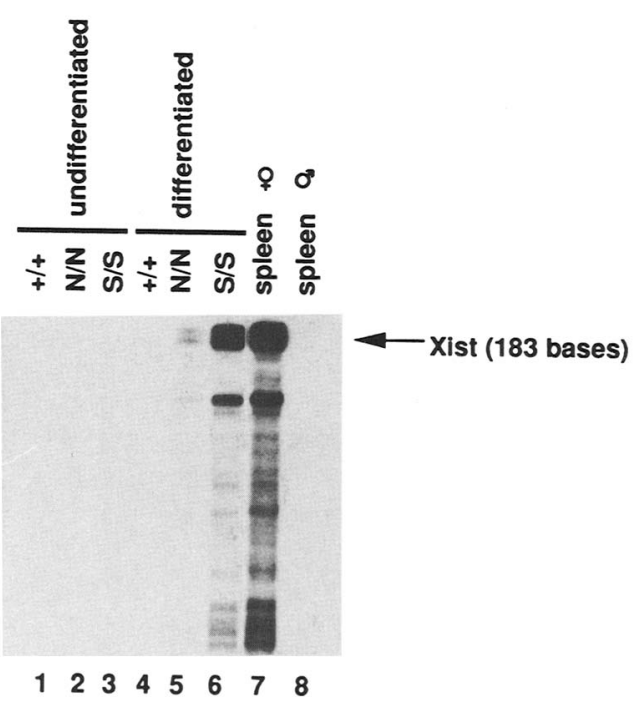

Figure 4. RNase protection analysis of Xist expression in undifferentiated and differentiated male ES cells. Samples of total RNA $(10 \mu \mathrm{g})$ isolated from undifferentiated (lanes 1-3) ES cells and ES cells differentiated for 15 days (lanes 4-6) were analyzed by RNase protection using a 254-base antisense RNA probe that hybridizes to sequences contained within exon V and VI of the Xist gene. The size of the protected fragment was 183 bases. RNAs from female (lane 7) and male (lane 8) adult spleen represent a positive and negative control, respectively. A cytoplasmic $\beta$-actin antisense RNA probe was used as a control to demonstrate the presence of RNA in all samples (data not shown). 
A

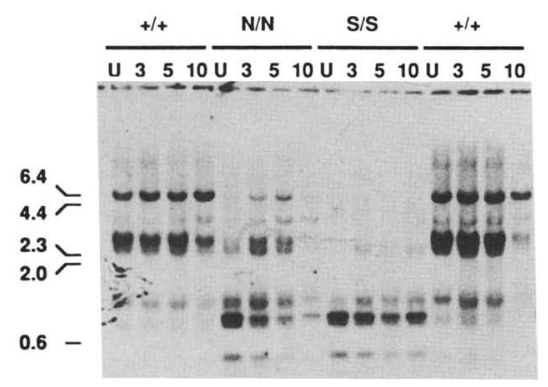

B

C

D
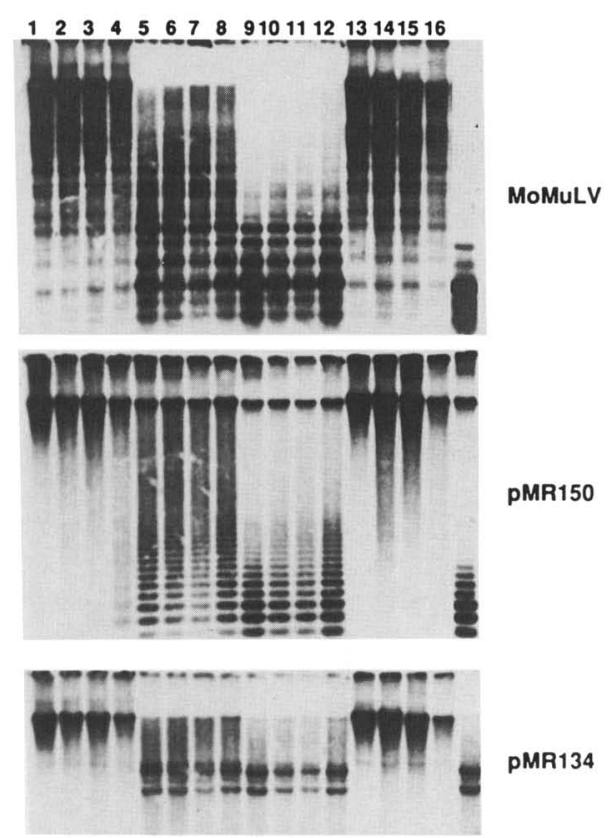

Figure 5. Demethylation of the Xist gene correlates with Xist expression in differentiated ES cells. Southern blot analysis of wild-type and Dnmt mutant male ES cells. $(A)$ Genomic DNAs $(10 \mu \mathrm{g})$ isolated from undifferentiated ES cells $(U)$ and 3,5 , and 10 days following differentiation were digested with EcORV and Hhal and hybridized with the $5^{\prime}$ Xist probe. V18 is a low passage male cell line. $(B, C, D)$ Ten micrograms of the same DNA as in $A$ was digested with HpaII and probed with MoMuLV to measure global methylation $(B)$. The blot was stripped and reprobed with either pMR150, which detects tandem centromeric repeat elements $(C)$, or pMR134, which detects $\mathrm{Ll}$ interspersed repetitive elements $(D)$. Lane 17 contains genomic DNA digested with the methylation insensitive restriction enzyme, MspI, as a marker for complete demethylation.

gene, which was only partially methylated (cf. Fig. 5A with B,C, and D, lanes 1 and 13). Similar results were obtained when the Southern blot shown in 5A lan EcoRV + Hhal digest) was hybridized to the MoMuLV probe (data not shown).

We conclude that the Xist gene, in contrast to other sites in the genome, is partially methylated in undifferentiated wild-type ES cells and that differentiation increases its methylation level. Substantial hypomethylation of the Xist gene is seen in ES cells homozygous for the Dnmt ${ }^{N}$ allele and, more so, in ES cells homozygous for the Dnmt ${ }^{\mathrm{S}}$ allele. The more pronounced hypometh- ylation seen in the latter cells correlates with increased expression, suggesting that methylation is causally involved in transcriptional repression of the Xist gene.

\section{Discussion}

The relationship between DNA methylation and Xist expression was investigated in embryos and ES cell lines that had differing degrees of hypomethylation produced by two alleles of the DNA methyltransferase gene. Specifically, we have shown that in male embryos homozygous for the weaker Dnmt ${ }^{\mathrm{N}}$ allele, the $5^{\prime}$ end of the Xist gene is fully methylated and the gene is not expressed. In contrast, male embryos homozygous for the most severe Dnmt $^{\mathrm{S}}$ mutation consistently expressed Xist with the gene being completely demethylated. Partial Xist methylation was seen in Dnmt ${ }^{\mathrm{N}} / \mathrm{Dnmt}^{\mathrm{S}}$ compound heterozygotes, only a fraction of which produced low levels of Xist RNA. Thus, the correlation between DNA methyltransferase levels, Xist methylation, and Xist expression provide clear in vivo evidence for a methylation mediated repression of Xist transcription in the postgastrulation embryo.

The results obtained with embryos in vivo were corroborated in male ES cells carrying the different Dnmt alleles. Xist activation was much more pronounced in the ES cells homozygous for the strong Dnmt ${ }^{\text {s }}$ allele than in the cells homozygous for the weaker Dnmt ${ }^{N}$ allele. Furthermore, the level of expression correlated with the degree of demethylation at the $5^{\prime}$ end of the Xist gene: The Dnmt's mutant ES cells were almost completely demethylated, whereas the Dnmt ${ }^{\mathrm{N}}$ mutant ES cells showed partial demethylation of the gene.

Interestingly, the RT-PCR results suggest that Xist is expressed in all ES cells prior to differentiation at a level low enough to escape detection by less sensitive techniques such as RNase protection. Preliminary in situ hybridization data are consistent with the Xist gene being expressed in undifferentiated ES cells (B. Panning and R. Jaenisch, in prep.). This expression is detectable in both male and female undifferentiated ES cells, suggesting that regulation of Xist expression prior to differentiation relies on a different mechanism that is both methylation and sex independent. What significance Xist expression may play at this stage and whether this in vitro result reflects an in vivo situation remains to be determined, but it is intriguing in light of Xist's role in initiating $\mathrm{X}$ inactivation.

Our results, in conjunction with results of an earlier study from our laboratory (Li et al. 1993), demonstrate that the methylation of certain sequences is preferentially maintained under conditions of limiting methyltransferase. We have shown that the Xist gene is more resistant to demethylation than the $I g f 2 r$ gene which, in turn, is more resistant than the $H 19$ gene. Complete demethylation at the $5^{\prime}$ end of the Xist gene was seen only in the most severe Dnmt ${ }^{\mathrm{s}}$ homozygous embryos, which do not have any detectable methyltransferase activity. The reason for the preferential maintenance of 
methylation of the Igf2r and Xist genes, which is clearly seen in embryos homozygous for the less severe Dnmt ${ }^{N}$ mutant allele, is not known. It is possible, for example, that specific sequence motifs, present in regions of the $X i s t$ and Igf2r genes, allow for more efficient binding of the DNA methyltransferase resulting in a preferential retention of methylation. In this regard, it has been shown that the human methyltransferase enzyme has an exceptional facility for actively methylating unusual DNA structures (Smith et al. 1991). Furthermore, direct tandem repeats, which are potentially able to form secondary structures, have been found in the putative imprinting box of the Igf2r gene (Neumann et al. 1995) and at the $5^{\prime}$ end of the Xist gene (Pfeifer and Tilghman 1994). These direct repeats are unique to the Igf2r and Xist genes and do not show any homology to the highly repeated DNA sequences in the mouse (Pfeifer and Tilghman 1994). The source of the methyltransferase activity that is responsible for the preferential methylation of the Igf2r and Xist genes is not known. It could be provided for by the low levels of maintenance methyltransferase that are detectable in the Dnmt ${ }^{\mathrm{N}}$ homozygous embryos and that would selectively methylate these sequences. Alternatively, another as yet undefined methyltransferase activity might be responsible for methylating certain sequences such as those present in the Igf2r and Xist genes. This latter possibility will be discussed below.

Although hypomethylation is essential for Xist expression in the postgastrulation embryo, in vitro data suggest that repression of Xist transcription in undifferentiated ES cells and, by implication in the pregastrulation embryo, may be independent of the methylation status of the gene. Thus, only a low level of Xist expression was seen in undifferentiated male wild-type and Dnmt mutant ES cells, although the gene was highly demethylated in the latter cells. Upon differentiation, however, demethylation of the gene appeared to be crucial for activating Xist transcription as Xist expression increased significantly only in the differentiated mutant but not in differentiated wild-type ES cells. These results suggest that in addition to demethylation of the Xist gene, repressors or activators of Xist expression are required for expression, and these factors are only present in differentiated ES cells or in embryos that have undergone gastrulation.

We and others (Norris et al. 1994) have noted a lower level of overall methylation of the HhaI sites at the 5' end of the Xist gene in wild-type undifferentiated ES cells relative to the level seen in somatic tissues. This partial methylation of the Xist gene in undifferentiated male ES cells stands in contrast to centromeric and interspersed repetitive sequences that are completely methylated. Upon differentiation, the level of $5^{\prime}$ Xist methylation, in contrast to the stable and even reduced level of methylation of endogenous retroviral sequences, appears to increase, consistent with methylation of the $X i s t$ gene playing an important role in the transcriptional repression of this gene in differentiated ES cells. We consider three possibilities to explain the apparent increase of Xist methylation.
Possibility 1 If Xist is responsible for $\mathrm{X}$ inactivation, its expression would result in cell lethality because of the silencing of essential genes on the single $\mathrm{X}$ chromosome. The apparent increase in methylation upon differentiation would, in this case, simply represent a selection for those cells that have a correctly methylated and, therefore, silent Xist gene. Prior to differentiation there would be no selective advantage to maintaining the methylation of the Xist gene, as repression of Xist transcription appears to be independent of the methylation status of the gene in undifferentiated cells.

Consistent with this possibility is the observation that undifferentiated $\mathrm{Dnmt}^{\mathrm{s}}$ mutant ES cells proliferate normally; however, upon induction of differentiation the $\mathrm{Dnmt}^{\mathrm{S}}$ cells do not appear to differentiate to the same extent as Dnmt ${ }^{\mathrm{N}}$ or wild-type ES cells, but rather they appear to die (H. Lei, P.S. Oh, R. Jütterman, R. Jaenisch, $\mathrm{K}$. Goss, and E. Li, in prep.). Also, undifferentiated $\mathrm{Dnmt}^{\mathrm{s}}$ mutant ES cells, in contrast to wild-type or $D \mathrm{nt}^{\mathrm{N}}$ mutant ES cells, injected subcutaneously into mice do not form teratomas (C. Beard, unpubl.). It is possible that the poor survival of differentiating Dnmt ${ }^{\mathrm{S}}$ mutant ES cells is attributable to the initiation of $\mathrm{X}$ chromosome inactivation induced by the expression of the Xist gene.

Possibility 2 A demethylating activity, responsible for the hypomethylation of the Xist gene, is present in undifferentiated ES cells. Upon differentiation, silencing of this demethylating activity would allow increased methylation of the Xist gene. As argued above, the increase in methylation of the Xist gene upon differentiation may simply reflect the ratio of differentiated and undifferentiated ES cells present in the culture.

Possibility 3 A distinct de novo methyltransferase activity, which specifically methylates Xist, may be activated only upon differentiation, and it is this activity that is responsible for random $\mathrm{X}$ inactivation in cells of the inner cell mass (ICM)/epiblast lineage as well as differentiating ES cells. Such an activity would result in increased methylation of the Xist gene upon differentiation of wild-type and Dnmt ${ }^{\mathrm{N}}$ mutant ES cells. However, there would be no or only a slight increase in methylation detectable in differentiated Dnmt ${ }^{5}$ mutant ES cells lacking the maintenance methyltransferase, as these cells would be unable to maintain the de novo methylation patterns through subsequent generations.

It is well established that hypomethylation, induced by treatment of tissue culture cells with the cytosine analog 5-aza dC, results in the activation of X-linked genes on the inactive $\mathrm{X}$ chromosome (Mohandas et al. 1981; Graves 1982; Paterno et al. 1985). If DNA demethylation also activated the inactive $\mathrm{X}$ chromosome in mutant embryos, mutant females with both $\mathrm{X}$ chromosomes activated would be genetically imbalanced and might be expected to die earlier than mutant males. This has not been observed, as male and female mutant embryos appear to die at the same time. Therefore, an im- 
portant issue raised by our results is whether demethylation-dependent expression of the Xist gene initiates the process of $X$ inactivation, which would lead to silencing of the active $\mathrm{X}$ chromosome in both males and females. Experiments to distinguish between these two possibilities are technically difficult due to the early embryonic lethality of the Dnmt mutant embryos and the rapid cell death associated with differentiating $\mathrm{Dnmt}^{\mathrm{s}}$ mutant ES cells. Preliminary RT-PCR analysis of the X-linked Pgk-1 gene in male Dnmt ${ }^{\mathrm{s}}$ mutant embryos and differentiated ES cells showed that Pgk-1 was being transcribed (data not shown). To test whether expression of this gene was decreased in differentiated Dnmt ${ }^{\mathrm{S}}$ ES cells relative to wild-type ES cells, we measured Pgk-1 RNA levels by RNase protection and found no significant difference in expression. However, because only a fraction of the cells in these cultures are differentiated at any time, we may not expect to see a reduction in Pgk-1 expression in the mutant ES cells if $\mathrm{X}$ chromosome inactivation, triggered by activation of Xist, contributes to rapid cell death. We are using other experimental approaches such as in situ analysis to clarify on the single cell level whether demethylation-induced Xist activation leads to silencing of other genes on the $\mathrm{X}$ chromosome.

\section{Materials and methods}

Mice

Mice were maintained in the facilities of the Whitehead Institute for Biomedical Research. Dnmt ${ }^{\mathrm{N}}$ and Dnmt (formally $^{\mathrm{S}}$ called MTase ${ }^{n}$ and MTases, respectively) have been described (Li et al. 1992, 1993; H. Lei, P.S. Oh, R. Jütterman, R. Jaenisch, $\mathrm{K}$. Goss, and $\mathrm{E}$. $\mathrm{Li}$, in prep.).

\section{Preparation of embryo tissues}

Decidua were dissected from the uterus and washed two times in ice-cold HEPES buffer to remove maternal blood. Embryos and yolk sac were removed from individual decidua and washed with three changes of ice-cold HEPES buffer before being quick frozen in liquid nitrogen. During the dissection care was taken to make sure that the yolk sac was free of any contaminating maternal tissue. Either the placenta or the yolk sac was used for genotyping and sexing of the embryos.

\section{Culture and differentiation of ES cells}

Male ES cell lines Il (wild-type for the Dnmt allele), Dnmt ${ }^{\mathrm{N}}$ (homozygous for the Dnmt ${ }^{\mathrm{N}}$ allele), and Dnmt ${ }^{\mathrm{S}}$ /homozygous for the Dnmt ${ }^{\mathrm{S}}$ allele) have been described (Li et al. 1992; H. Lei, P.S. Oh, R. Jütterman, R. Jaenisch, K. Goss, and E. Li, in prep.). V18, a male ES cell line derived from $129 / \mathrm{SV}$ mice, and V44, a female ES cell line derived from a BALB/c $\times(129 / \mathrm{SV} \times \mathrm{BALB} / \mathrm{c}) \mathrm{F}_{1}$, were isolated in this laboratory by Martina Klemm (The Whitehead Institute, Cambridge, MA). Cell lines were maintained in the undifferentiated state by culture on FVB-derived $\gamma$-irradiated male EF cells in HEPES-buffered Dulbecco's modified Eagle medium (DMEM) supplemented with $15 \%$ fetal calf serum, $0.1 \mathrm{~mm}$ nonessential amino acids (GIBCO), $0.1 \mathrm{~mm} \beta$-mercaptoethanol, antibiotics, and 500 units of leukemia inhibitory factor (LIF)/ $\mathrm{ml}$. ES cells were passaged two times without feeders onto ge- latinized tissue culture plates to ensure that there was no feeder contamination in the samples. ES cells were induced to differentiate into embryoid bodies by suspension culture in bacteriological petri dishes as described (Robertson 1987). Samples were collected at various times for isolation of RNA and DNA. Cell pellets were washed with HEPES and stored at $-80^{\circ} \mathrm{C}$.

\section{Isolation of RNA and DNA from embryos and ES cells}

RNA was prepared from embryos and ES cells by the guanidinium isothiocyanate/phenol/chloroform method (Chomczynski and Sacchi 1987). For preparation of RNA from individually frozen embryos or yolk sacs, $10 \mu \mathrm{g}$ of yeast transfer RNA was added as carrier. Purified RNA was treated with 2 units of RNase-free DNase (BRL) for $45 \mathrm{~min}$ at $37^{\circ} \mathrm{C}$. The RNA was phenol extracted and ethanol precipitated.

DNA was prepared from individual embryos or yolk sacs by a modification of the method of Laird et al. (1991). Samples were incubated at $37^{\circ} \mathrm{C}$ overnight in $200 \mu \mathrm{l}$ of buffer (100 mM Tris at $\mathrm{pH} 8.0,5 \mathrm{~mm}$ EDTA, $0.2 \%$ SDS, $200 \mathrm{~mm} \mathrm{NaCl}$, and $200 \mu \mathrm{g}$ of proteinase $\mathrm{K} / \mathrm{ml}$ ) containing $10 \mu \mathrm{g}$ of yeast tRNA. DNA from ES cells was processed by the same procedure but without the addition of yeast tRNA as carrier. Samples were extracted with phenol and precipitated with an equal volume of isopropanol.

\section{Southern blot analysis}

Genotypes were established by Southern blot analysis of DNA isolated from the yolk sac or placenta of individual embryos as described above. Purified DNA was digested with restriction enzymes, fractionated by electrophoresis through $0.8 \%$ agarose gels, blotted with $0.4 \mathrm{M} \mathrm{NaOH}$ onto Gene Screen Plus (DuPontNEN), and hybridized with either the pBB probe for $\operatorname{Dnmt}^{\mathrm{N}}(\mathrm{Li}$ et al. 1992) or the pHH probe for Dnmts (H. Lei, P.S. Oh, R. Jütterman, R. Jacnisch, K. Goss, and $\mathrm{E}$. $\mathrm{Li}$, in prep.l. These blots were then stripped by treatment of the filters with $0.4 \mathrm{M}$ $\mathrm{NaOH}$ for $30 \mathrm{~min}$ at $37^{\circ} \mathrm{C}$ and then hybridized with a $\mathrm{Y}$-specific probe (Lamar and Palmer 1984) for sexing individual embryos. Probes for Southern hybridization were gel purified and labeled with $\left|{ }^{32} \mathrm{P}\right| \mathrm{dCTP}$ by random hexamer priming (Feinberg and Vogelstein 1984).

To examine DNA methylation at CCGG sites, DNA was digested with EcoRV+HhaI (Xist analysis), Sacl + Hpall (H19 analysis), or HpaII (MoMuLV, pMR150, and pMR134 analyses) according to the manufacturer's recommendations, electrophoresed, and blotted as described above. The following probes were used: 5'Xist plasmid (kindly provided by Huntington Willard, Case Western Reserve University, Cleveland, $\mathrm{OH}$ ) contains a $1.5-\mathrm{kb}$ mouse cDNA fragment that includes the start site of transcription and $1.5 \mathrm{~kb}$ of exon 1 . The $H 19$ plasmid /kindly provided by Shirley Tilghman/ contains a 4.0-kb EcoRI genomic fragment that lies upstream of the $5^{\prime}$ end of the gene (Bartolomei et al. 1993). The MoMuLV probe is a $5.5-\mathrm{kb}$ cDNA fragment (Jahner et al. 1982). pMR150 and pMR134 are plasmids (kindly provided by Verne Chapman, Roswell Park Cancer Institute, Buffalo, NY) that represent the minor satellite and dispersed LI repeat sequences, respectively (Voliva et al. 1983).

\section{First-strand synthesis}

Approximately 1-2 $\mu \mathrm{g}$ of RNA (DNase treated) was annealed to $1 \mu \mathrm{g}$ of random hexamers at $65^{\circ} \mathrm{C}$ for $5 \mathrm{~min}$ in a volume of $12 \mu \mathrm{l}$. Samples were quick cooled on ice and $8 \mu \mathrm{l}$ of reverse transcriptase mix, which contained $1.25 \mathrm{~mm}$ dNTPs, $25 \mathrm{~mm}$ DTT, 20 units of RNasin (Promega), 100 units of M-MLV reverse tran- 
scriptase (BRL) and $4 \mu \mathrm{l}$ of $5 \times \mathrm{xM}-\mathrm{MLV}$ reaction buffer (BRL), were added. Reactions were incubated at $37^{\circ} \mathrm{C}$ for $1 \mathrm{hr}$.

\section{PCR reactions}

First strand synthesis $(1-10 \mu \mathrm{l})$ was amplified by PCR in a total volume of $20-30 \mu \mathrm{l}$ per reaction. PCR reactions contained 50 $\mathrm{mm} \mathrm{KCl}, 10 \mathrm{~mm}$ Tris at $\mathrm{pH} 9.0,0.1 \%$ Triton X-100, $1.5 \mathrm{~mm}$ $\mathrm{MgCl}_{2}, 0.2 \mathrm{mM} \mathrm{dNTP}, 0.6 \mu \mathrm{M}$ each of forward and reverse primers, and 0.05 units of Taq polymerase (Promega)/ $\mu$ l of reaction. The amplifications consisted of denaturation at $95^{\circ} \mathrm{C}$ for $5 \mathrm{~min}$, followed by 30 cycles of PCR amplification at $95^{\circ} \mathrm{C}$ for $1 \mathrm{~min}$, $55^{\circ} \mathrm{C}$ for $1 \mathrm{~min}$, and $72^{\circ} \mathrm{C}$ for $2 \mathrm{~min}$, and a 10 -min extension at $72^{\circ} \mathrm{C}$. Products were analyzed by electrophoresis in a $2 \%$ agarose gel and staining with ethidium bromide.

The primers used for Xist amplification were MIX 20 and MX 23 (Kay et al. 1993). FGF-5 forward and reverse primers amplify a 310-bp sequence from exon 3 . The sequence of FGF-F is 5'-CGGATGACTGTAAGTTCAGG-3' and the FGF-R is $5^{\prime}$ TCAGTCTGTACTTCACTGGG-3'. Primers used for detecting DNA methyltransferase were Sal5' '5' -AGTCGCGGGCACCTGTGTCC-3') and Sal3' (5'-CCACTGATTGATTGGCCCGAGC-3'). These primers amplify a sequence that includes the SalI site (position 1198) in the cDNA.

\section{RNase protection}

Total RNA $\left(\sim 10 \mu \mathrm{g} /\right.$ lane) was hybridized with $2 \times 10^{5} \mathrm{cpm}$ of antisense Xist RNA probe in a volume of $20 \mu \mathrm{l}$ containing $80 \%$ deionized formamide, $40 \mathrm{~mm}$ HEPES at $\mathrm{pH} 7.9$, and $400 \mathrm{~mm}$ $\mathrm{NaCl}$. The RNA probe, which was 254 bases and included polylinker sequence and positions 9604-10181 of the mouse Xist gene, was gel purified on a denaturing $7 \%$ acrylamide, $7 \mathrm{M}$ urea gel and eluted in $400 \mu \mathrm{l}$ buffer containing $10 \mathrm{~mm}$ Tris at $\mathrm{pH} 8.0$, $0.1 \%$ SDS, and $10 \mu \mathrm{g}$ of yeast tRNA. The samples were denatured at $65^{\circ} \mathrm{C}$ for $5 \mathrm{~min}$ and hybridized overnight at $50^{\circ} \mathrm{C}$. Samples were processed using the Guardian RNase Protection Assay Kit (Clontech) according to the manufacturer's instructions. RNase was diluted $1: 25$, and digestions were carried out at $30^{\circ} \mathrm{C}$ for $30 \mathrm{~min}$. Products were analyzed on a denaturing $7 \%$ acrylamide gel containing $7 \mathrm{M}$ urea.

\section{Acknowledgments}

We thank Huntington Willard for the plasmid containing the $5^{\prime}$ Xist probe, Verne Chapman for the plasmids containing the repeat sequence inserts, Shirley Tilghman for the H19 probe, and Jeannie Lee and York Marahrens for helpful discussion and critical reading of the manuscript. This work was supported by a grant to E.L. from Bristol-Meyers and Squibb and to R.J. from the National Institutes of Health/National Cancer Institute (R35-CA44339).

The publication costs of this article were defrayed in part by payment of page charges. This article must therefore be hereby marked "advertisement" in accordance with 18 USC section 1734 solely to indicate this fact.

\section{References}

Ariel, M., E. Robinson, J.R. McCarrey, and H. Cedar. 1995. Gamete-specific methylation correlates with imprinting of the murine Xist gene. Nature Genet. 9: 312-315.
Bartolomei, M.S., A.L. Webber, M.E. Brunkow, and S.M. Tilghman. 1993. Epigenetic mechanisms underlying the imprinting of the mouse $H 19$ gene. Genes \& Dev. 7: 1663-1673.

Borsani, G., R. Toniorenzi, M.C. Simmler, L. Dandolo, D. Arnaud, V. Capra, M. Grompe, A. Pizzuti, D. Munzy, C. Lawrence, H.F. Willard, P. Avner, and A. Ballabio. 1991. Characterization of a murine gene expressed from the inactive X chromosome. Nature 351: 325-329.

Brandeis, M., T. Kafri, M. Ariel, J.R. Chaillet, J. McCarrey, A. Razin, and H. Cedar. 1993. The ontogeny of allele-specific methylation associated with imprinted genes in the mouse. EMBO I. 12: 3669-3677.

Brockdorff, N., A. Ashworth, G.F. Kay, P. Cooper, S. Smith, V.M. McCabe, D.P. Norris, G.D. Penny, D. Patel, and S Rastan. 1991. Conservation of position and exclusive expression of mouse Xist from the inactive $\mathrm{X}$ chromosome. Nature 351: 329-331.

Brown, C.J., R.G. Lafreniere, V.E. Powers, G. Sebastio, A. Ballabio, A.L. Pettigrew, D.H. Ledbetter, E. Levy, I.W. Craig, and H.F. Willard. 1991. Localization of the $\mathrm{X}$ inactivation centre on the human X chromosome in Xq13. Nature 349: 82-84.

Cattanach, B.M. 1975. Control of chromosome inactivation. Annu. Rev. Genet. 9: 1-18.

Chapman, V.M., L. Forrester, J. Sanford, N. Hastie, and J. Rossant. 1984. Cell lineage-specific undermethylation of mouse repetitive DNA. Nature 307: 284-286.

Chomczynski, P. and N. Sacchi. 1987. Single-step method of RNA isolation by acid guanidinium thiocyanate-phenolchloroform extraction. Anal. Biochem. 162: 156-159.

Conover, J.C., N.Y. Ip, W.T. Poueymirou, B. Bates, M.P. Goldfarb, C.T. De, and G.D. Yancopoulos. 1993. Ciliary neurotrophic factor maintains the pluripotentiality of embryonic stem cells. Development 119: 559-565.

Feinberg, A.P. and B. Vogelstein. 1984. A technique for radiolabeling DNA restriction endonuclease fragments to high specific activity. Addendum. Anal. Biochem. 137: 266-267.

Ferguson, S.A., H. Sasaki, B.M. Cattanach, and M.A. Surani. 1993. Parental-origin-specific epigenetic modification of the mouse H19 gene. Nature 362: 751-755.

Gardner, R.L. and M.F. Lyon. 1971. X chromosome inactivation studied by injection of a single cell into the mouse blastocyst. Nature 231: 385-386.

Graves, J.A.M. 1982. 5-Azacytidine-induced re-expression of alleles on the inactive $\mathrm{X}$ chromosome in a hybrid mouse cell line. Exp. Cell Res. 141: 99-105.

Harper, M.I., M. Fosten, and M. Monk. 1982. Preferential paternal $\mathrm{X}$ inactivation in extraembryonic tissues of early mouse embryos. I. Embryol. Exp. Morphol. 67: 127-135.

Hebert, J.M., M. Boyle, and G.R. Martin. 1991. mRNA localization studies suggest that murine FGF-5 plays a role in gastrulation. Development 112: 407-415.

Jahner, D., H. Stuhlmann, C.L. Stewart, K. Harbers, J. Lohler, I. Simon, and R. Jaenisch. 1982. De novo methylation and expression of retroviral genomes during mouse embryogenesis. Nature 298: 623-628.

Kay, G.F., G.D. Penny, D. Patel, A. Ashworth, N. Brockdorff, and S. Rastan. 1993. Expression of Xist during mouse development suggests a role in the initiation of $\mathrm{X}$ chromosome inactivation. Cell 72: 171-182.

Laird, P.W., A. Zijderveld, K. Linders, M.A. Rudnicki, R. Jaenisch., and A. Berns. 1991. Simplified mammalian DNA isolation procedure. Nucleic Acids Res. 19: 4293.

Lamar, E.E. and E. Palmer. 1984. Y-encoded, species-specific DNA in mice: Evidence that the $\mathrm{Y}$ chromosome exists in two polymorphic forms in inbred strains. Cell 37: 171-177.

Li, E., T.H. Bestor, and R. Jaenisch. 1992. Targeted mutation of 
the DNA methyltransferase gene results in embryonic lethality. Cell 69: 915-926.

Li, E., C. Beard, and R. Jaenisch. 1993. Role for DNA methylation in genomic imprinting. Nature 366: 362-365.

Lyon, M.F. 1961. Gene action in the X chromosome of the mouse (Mus musculus). Nature 190: 372-373.

Mattei, J.F., M.G. Mattei, M.A. Baeteman, and F. Giraud. 1981. Trisomy 21 for the region 21q223: Identification by highresolution R-banding patterns. Hum. Genet. 56: 409-411.

Mohandas, T., R.S. Sparkes, and L.J. Shapiro. 1981. Reactivation of an inactive human $\mathrm{X}$ chromosome: Evidence for X-inactivation by DNA methylation. Science 211: 393-396.

Monk, M. and M.I. Harper. 1979. Sequential X-chromosome inactivation coupled with cellular differentiation in early mouse embryos. Nature 281: 311-313.

Neumann, B., P. Kubicka., and D.P. Barlow. 1995. Characteristics of imprinted genes. Nature Genet. 9: 12-13.

Norris, D.P., D. Patel, G.F. Kay, G.D. Penny, N. Brockdorff, S.A. Sheardown, and S. Rastan. 1994. Evidence that random and imprinted Xist expression is controlled by preemptive methylation. Cell 77: 41-51.

Papaioannou, V.E., J.D. West, T. Bucher, and I.M. Linke. 1981. Non-random X-chromosome expression early in mouse development. Dev. Genet. 2: 305-315.

Paterno, G.D., C.N. Adra, and M.W. Mc Burney. 1985. X chromosome reactivation in mouse embryonal carcinoma cells. Mol. Cell. Biol. 5: 2705-2712.

Pfeifer, K. and S.M. Tilghman. 1994. Allele-specific gene expression in mammals: The curious case of the imprinted RNAs. Genes \& Dev. 8: 1867-1874.

Rastan, S. 1982. Timing of X-chromosome inactivation in postimplantation mouse embryos. I. Embryol. Exp. Morphol. 71: 11-24.

Robertson, E.J. 1987. Embryo-derived stem cells. In Teratocar cinomas and Embryonic Stem Cells /ed. D. Rickwood and B.D. Hames), pp. 71-112. IRL Press, Oxford, UK.

Russell, L.B. 1963. Mammalian X-chromosome action: Inactivation limited in spread and in region of origin. Science 140: 976-978.

Smith, S.S., J.L. Kan, D.J. Baker, B.E. Kaplan, and P. Dembe. 1991. Recognition of unusual DNA structures by human DNA (cytosine-5) methyltransferase. $/$. Mol. Biol. 217: 3951.

Stuhlmann, H., D. Jahner, and R. Jaenisch. 1981. Infectivity and methylation of retroviral genomes is correlated with expression in the animal. Cell 26: 221-232.

Takagi, N. 1974. Differentiation of X chromosomes in early female mouse embryos. Exp. Cell Res. 86: 127-135.

Takagi, N. and M. Sasaki. 1975. Preferential inactivation of the paternally derived $\mathrm{X}$ chromosome in the extraembryonic membranes of the mouse. Nature 256: 640-642.

Therman, E., G.E. Sarto, and K. Patau. 1974. Center for Barr body condensation on the proximal part of the human $\mathrm{Xq}$ : $\mathrm{A}$ hypothesis. Chromosoma 44: 361-366.

Voliva, C.F., C.L. Jahn, C.A. Comer, C.A. Hutchinson III, and M.H. Edgell. 1983. The LlMd long interspersed repeat family in the mouse: Almost all examples are truncated at one end. Nucleic Acids Res. 11: 8847-8859.

West, J.D., W.I. Frels, V.M. Chapman, and V.E. Papaioannou. 1977. Preferential expression of the maternally derived $\mathrm{X}$ chromosome in the mouse yolk sac. Cell 12: 873-882.

Zuccotti, M. and M. Monk. 1995. Methylation of the mouse Xist gene in sperm and eggs correlates with imprinted Xist expression and paternal X-inactivation. Nature Genet. 9: $316-320$. 


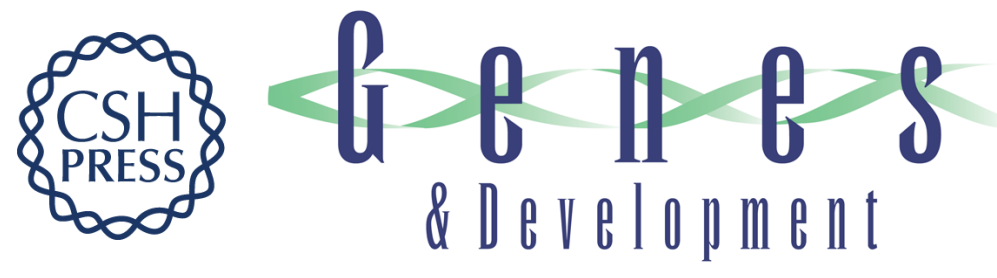

\section{Loss of methylation activates Xist in somatic but not in embryonic cells.}

C Beard, E Li and R Jaenisch

Genes Dev. 1995, 9:

Access the most recent version at doi:10.1101/gad.9.19.2325

References This article cites 41 articles, 7 of which can be accessed free at:

http://genesdev.cshlp.org/content/9/19/2325.full.html\#ref-list-1

License

Email Alerting

Service

Receive free email alerts when new articles cite this article - sign up in the box at the top right corner of the article or click here.

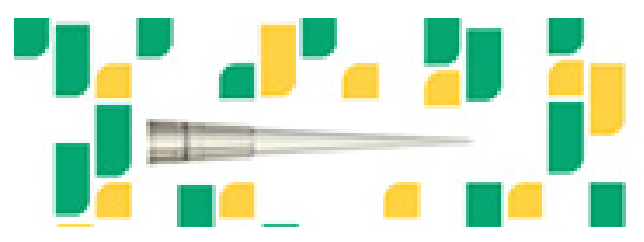

Focused on your science. 